\title{
POTRET ISLAM REVOLUSIONER DALAM PEMIKIRAN ALI SYARI'ATI
}

\author{
Oleh: \\ Anjar Nugroho \\ Universitas Muhammadiyah Purwokerto \\ Email: anjarnugroho75@gmail.com
}

\begin{abstract}
Abstrak: Ali Syari'ati adalah contoh intelektual sui generis yang berani dalam posisi melawan mainstreem politik maupun pemikiran Islam. Pemahaman Islam yang ditawarkan Ali Syari'ati berbeda dengan pemahaman maintreem saat itu. Islam yang dipahami banyak orang di masa Syari'ati adalah Islam yang hanya sebatas agama ritual dan fiqh yang tidak menjangkau persoalanpersoalan politik dan sosial kemasyarakatan. Dalam pemikiran Syari'ati, Islam bukanlah agama yang hanya memperhatikan aspek spiritual dan moral atau hanya sekadar hubungan antara hamba dengan Sang Khaliq (Hablun min Allah), tetapi lebih dari itu, Islam adalah sebuah ideologi emansipasi dan pembebasan.
\end{abstract}

Kata Kunci: Ali Syari'ati, Islam Pembebasan, dan Tauhid

\section{Pendahuluan}

Ali Syari'ati adalah contoh intelektual sui generis yang berani dalam posisi melawan mainstreem politik maupun pemikiran Islam.Ia dapat disejajarkan dengan para pembaharu Sunni pendahulunya, seperti Jamal al-Din al-Afghani (w.1897), Muhammad Abduh (w. 1905) atau Muhammad Iqbal (w.1938). Sama dengan Syari'ati, mereka adalah pembaharu pemikiran Islam dan sekaligus para oposan yang sangat kritis dengan fenomena ketidakadilan dan imperialisme Barat.Yang membedakan antara Syari'ati dengan ketiga tokoh Sunni itu adalah bahwa Syari'ati lebih radikal dalam mengimplementasikan pemikiran-pemikiran pembaharuannya dan ini yang perlu mendapat catatan tebal sejarah pembaharuan Islam, bahwa Syari'ati dengan gagasan revolusinya berhasil menarik gerbong oposisi di kalangan masyarakat Iran untuk melawan rezim yang berkuasa sampai akhirnya gerakan oposisi itu berhasil melakukan revolusi bersejarah tahun 1979.

Pemahaman Islam yang ditawarkan Ali Syari'ati berbeda dengan pemahaman maintreem saat itu. Islam yang dipahami banyak orang di masa Syari'ati adalah Islam yang hanya sebatas agama ritual dan fiqh yang tidak menjangkau persoalan-persoalan politik dan sosial kemasyarakatan. Islam hanyalah sekumpulan dogma untuk mengatur bagaimana beribadah tetapi tidak menyentuh sama sekali cara yang paling efektif untuk menegakkan keadilan, strategi 
melawan kezaliman atau petunjuk untuk membela kaum tertindas (mustad'afîn). Dalam istilah alQur'an, istid'âf bukan berarti “kelemahan atau keputusasaan”. Itu merupakan kata jadian yang sama dengan istibdâd (despotisme), isti'mâr (kolonialisme), istismâr (eksploitasi), dan seterusnya. Dalam kenyatannya, yang terakhir itu merupakan bentuk-bentuk istid'âf (penindasan) yang telah terjadi di berbagai masa sejarah. Setiap kali rakyat dibiarkan lemah secara ekonomis (eksploitasi), politis (despotisme), nasionalis (kolonialisme), dan kultural (pelumpuhan), entah di dalam satu bidang ini atau gabungan beberapa diantaranya, maka terjadilah istid'âf dan korbankorbannya dinamakan mustad'afin (yang tertindas) (Ali Syari'ati, 1986:1-2). Islam yang demikian itu dalam banyak kesempatan sangat menguntungkan pihak penguasa yang berbuat sewenangwenang dan mengumbar ketidakadilan, karena ia bisa berlindung di balik dogma-dogma yang telah dibuat sedemikian rupa untuk melindungi kepentingannya.

Dalam konteks situasi politik saat Syari'ati hidup, wacana Islam mainstreem itulah yang digunakan oleh sebagian besar ulama untuk mendukung kekuasaan rezim Syah.Ketika rezim Syah menindas rakyatnya, para ulama rezimis tersebut tidak mampu berbuat apa-apa untuk kepentingan rakyat.Justru ulama itu dipaksa untuk terus-menerus memberikan justifikasi keagamaan atas kebijakan-kebijakan Syah. Syari'ati menganalogkan Islam yang demikian itu sebagai Islam gaya penguasa (Islamnya Usman, Khalîfah ketiga Islam). Sementara Islam otentik, sebagaimana yang dinyatakan Syari'ati, adalah Islamnya Abu Zar, sahabat Nabi sang pencetus pemikiran sosialistik Islam:

Abu Dhar was watching these shameful scenes and because he could no longer bear it, could no longer remain silent, he rebelled, a manly and wonderful rebellion; an prising which caused rebellion in all the Islamic lands against 'Uthman; an uprising from which the waves of enthusiasm can still be felt until the present day in the situations of human societies. Abu Dhar was trying to develop the economic and political unity of Islam and the regime of 'Uthman was reviving aristocracy. Abu Dhar believed Islam to be the refuge of the helpless, the oppressed and the humiliated people and 'Uthman, the tool of capitalism, was the bastion to preserve the interests of the usurers, the wealthy and the aristocrats. (Abu Zar menyaksikan peristiwa yang memalukan ini dan karena tidak bisa lagi menerima hal itu itu, maka dia tidak lagi bisa diam, ia pun melawan, suatu perlawanan yang sangat bagus dan jantan; suatu perlawanan yang menyebabkan timbulnya perlawanan di semua wilayah Islam melawan kekuasaanUsman; suatu perlawanan dari gelombang gairah Islam yang tetap dirasakan sampai zaman sekarang di dalam sejarah umat manusia. Abu Zar sedang berusaha untuk membangun kesatuan ekonomi dan politik Islam dan rejim Usman sedang menghidupkan kembali aristocracy. Abu Zar percaya Islam sebagai tempat perlindungan orang yang membutuhkan pertolongan, si tertindas dan orang-orang yang terhina dan 'Usman menjadikan Islam sebagai alat kapitalisme yang berarti pula benteng untuk memelihara para lintah darat, orang-orang kaya dan kaum ningrat.) (Ali Syari'ati "And Once Again Abu-Dhar", dalam 
http://www.iranchamber.com/personalities/ashariati/works/once_again_abu_dhar7.php, diakses tanggal 22 Pebruari 2006)

\section{Watak Pembebasan Islam}

Islam, dalam pandangan Syari'ati bukanlah agama yang hanya memperhatikan aspek spiritual dan moral atau hanya sekadar hubungan antara hamba dengan Sang Khaliq (Hablu min Allah), tetapi lebih dari itu, Islam adalah sebuah ideologi emansipasi dan pembebasan:

Adalah perlu menjelaskan tentang apa yang kita maksud dengan Islam. Dengannya kita maksudkan Abu Zar; bukan Islamnya Khaliffah .Islam keadilan dan kepemimpinan yang pantas; bukan Islamnya penguasa, aristokrasi dan kelas atas.Islam kebebasan, kemajuan (progress) dan kesadaran; bukan Islam perbudakan, penawanan dan pasivitas.Islam kaum mujâhid; bukan Islamnya kaum ulama.Islam kebajikan dan tanggungjawab pribadi dan protes; bukan Islam yang menekankan dissimulasi (taqiyeh) keagamaan, wasilah ulama dan campur tangan Tuhan.Islam perjuangan untuk keimanan dan pengetahuan ilmiah; bukan Islam yang menyerah, dogmatis, dan imitasi tidak kritis (taqlîd) kepada ulama (Azyumardi Azra, 1996: 77).

Selanjutnya, gambaran Islam pembebasan ditegaskan kembali oleh Syari'ati:

Adalah tidak cukup dengan menyatakan kita harus kembali kepada Islam. Kita harus menspesifikasi Islam mana yang kita maksudkan: Islam Abu Zar atau Islam Marwan (bin. Affan), sang penguasa. Keduanya disebut Islam, walaupun sebenarnya terdapat perbedaan besar diantara keduanya.Satunya adalah Islam ke-khalîfah-an, istana dan penguasa.Sedangkan lainnya adalah Islam rakyat, mereka yang dieksploitasi dan miskin.Lebih lanjut, tidak cukup syah dengan sekadar berkata, bahwa orang harus mempunyai kepedulian (concern) kepada kaum miskin dan tertindas.Khalîfah yang korup juga berkata demikian. Islam yang benar lebih dari sekedar kepedulian.Islam yang benar memerintahkan kaum beriman berjuang untuk keadilan, persamaan dan penghapusan kemiskinan (Muhammad Nafis dalam M. Deden Ridwan, 1999: 61).

Islam pembebasan adalah Islam yang diwariskan oleh Imam Husein; kesyahidannya di Karbala menjadi sumber inspirasi bagi mereka yang tertindas untuk memelihara Islam yang otentik itu. Sehingga, Islam yang demikian adalah Islam Syi'ah awal, yakni Islam Syi'ah revolusioner yang dipersonifikasikan Abu Zar al-Ghifari dengan kepapaannya, dan Imam Husein dengan kesyahidannya. Keduanya merupakan simbol perjuangan abadi ketertindasan melawan penguasa yang zalim.Islam Syi'ah revolusioner ini kemudian mengalami "penjinakan" di tangan kelas atas - penguasa politik dan ulama yang memberikan legitimasi atas "Islam" versi penguasa. Ulama, tuduh Syari'ati dengan menggunakan jargon Marxis, telah menyunat Islam dan melembagakannya sebagai "pemenang" (pacifier) bagi massa tertindas, sebagai dogma kaku dan 
teks skriptural yang mati. Ulama bergerak seolah-olah di dalam kevakuman, terpisah dari realitas sosial (Azyumardi Azra, 1996: 77-78).

Kenyataan ini, menurut Syari'ati, misalnya, terlihat pada masa Safawi, dimana dinasti penguasa memasyarakatkan Syi'isme versi mereka sendiri yang sangat berbeda dengan Syi'ah Imam Ali dan Imam Husein. Syari'ati, menyebut jenis Syi'ah penguasa sebagai "Syi'ah Hitam (Black Shi'ism)", dan Syi'ah Imam Ali sebagai “Syi'ah Merah (Red Shi'ism)", yakni Syi'ah kesyahidah (Shi'ism of martyrdom).

Shi'ites take their slogans from the embodiment of the tribulations and hopes of the masses of the oppressed. Aware of the rulers, and in rebellion against them, they cry out: "Seek the leadership of Ali and flee from the leadership of cruelty. Choose Imamate, and stamp 'cancelled,' 'disbelief' and 'dispossession' upon the forehead of the Caliphate.Choose justice, and overthrow the system of paradox and discrimination in ownership. Choose the principle of being ready to protest against the existing conditions, where the ruling government, religious leaders and aristocracy try to show that everything is in accordance with the Will of God, the Divine Law and the satisfaction of God and his creatures. Such things, to the ruling government, included their conquests, their plundering of mosques, associations, schools, gifts, trusts, and charities and the observance of religious ceremonies and practices.... And this is the last revolutionary wave of Alavite Shi'ism, Red Shi'ism, which continued for seven hundred years to be the flame of the spirit of revolution, the search for freedom, and justice, always inclining towards the common people and fighting relentlessly against oppression, ignorance and poverty. A century later came the Safavids, and Shi'ism left the great mosque of the common people to become a next-door neighbor to the Palace of 'Ali Qapu in the Royal Mosque. Red Shi'ism changes to Black Shi'ism! The Religion of Martyrdom changes to The Religion of Mourning.

(Syi'ah mengambil semboyan mereka (Imam Ali, Hasan, Husein, dan Zaenab) dari perwujudan harapan kesengsaraan rakyat jelata, orang-orang tertindas. Sadar akan hadirnya para penguasa (zalim), dan selalu memberontak melawan mereka. Mereka menangis histeris dan beriak : "Lihatlah itu kepemimpinan Ali yang lari dari kepemimpinan yang kejam. Pilihlah imâmah (kepemimpinan), pilihlah keadilan, dan robohkan sistem paradok dan diskriminasi di dalam kepemilikan. Pilihkah prinsip untuk selalu siap memprotes atas kondisi sosial politik yang ada, di saat para penguasa, para ulama dan bangsawan mencoba untuk menunjukkan segala hal itu sebagai kehendak Tuhan, Hukum Tuhan. Kehendak itu mewujud dalam menaklukkan mereka, merampas masjid mereka, perkumpulan, hadiah, kepercayaan, derma dan ketaatan dalam menjalankan upacara keagamaan... Dan ini adalah gelombang Syi'ah revolusioner, yakni Syi'ah Merah, yang selama tujuh ratus tahun menyalakan ruh revolusi, mencari kebebasan dan keadilan, berpihak kepada rakyat dan berani melawan berbagai tekanan, kemiskinan dan kebodohan. Satu abad kemudian datanglah Dinasti Safawi, dan Syi'ah telah (dipaksa) meninggalkan masjid besar milik bersama rakyat untuk menjadi penghuni masjid istana raja. Syi' ah Merah berubah menjadi Syi'ah Hitam! Agama Kesyahidan berubah menjadi agama berkabung.) (Ali Syari'ati, "Red Shi'ism (the religion of martyrdom) vs. Black Shi'ism (the religion of mourning)", dalam http://www.iranchamber.com/personalities/ashariati/works/red_black_shiism.php, diakses tanggal 20 Pebruari 2006) 
Menurut pengamatan Syari'ati, selama 7 abad sampai masa Dinasti Safavi, Syi'isme (Alavi) merupakan gerakan revolusioner dalam sejarah, yang menentang seluruh rezim otokratik yang mempunyai kesadaran kelas seperti Dinasti Ummayah, Abbasiyah, Ghaznawiyah, Saljuk, Mongol, dan lain-lain. Dengan legitimasi ulama rezim-rezim ini menciptakan Islam Sunni versi mereka sendiri. Pada pihak lain, Islam Syi'ah Merah, seperti sebuah kelompok revolusioner, berjuang untuk membebaskan kaum yang tertindas dan pencari keadilan.

Syari'ati melihat rezim dan lembaga keulamaan, yang bisa jadi terkadang ditunggangi pihak luar, sebagai manipulator masa lampau Iran dan arsitek yang menjadikan tradisi menjadi penjara.Rezim Syah Iran tidak membangkitkan agama, tetapi mempertahankan kerajaan yang mandek, sementara para ulama mempertahankan kemandekan Islam. Menurut Syari'ati, apa yang terjadi di Iran adalah, bahwa di satu sisi, para ulama yang menjadi pemimpin agama selama dua abad terakhir telah mentransformasikannya menjadi bentuk agama yang kian mandek, sementara di sisi lain orang-orang yang tercerahkan yang memahami kekinian dan kebutuhan generasi dan zaman, tidak memahami agama. Akhirnya, kata Syari'ati, "Islam sejati tetap tak diketahui dan tersembunyi dalam relung-relung sejarah". (Ali Syari’ati, 1986: 21).

Bagi Syari'ati, Islam sejati bersifat revolusioner, dan Syi'ah sejati adalah jenis khusus Islam revolusioner. (Robert D. Lee, 2000: 140) Tetapi entah mengapa dalam perjalanan waktu kemudian Islam telah berubah menjadi seperangkap doa-doa dan ritual yang tak bermakna sama sekali dalam kehidupan. Islam hanya sebatas agama yang mengurus bagaimana orang mati, tetapi tidak peduli bagaimana orang bisa survive dalam kehidupan di tengah gelombang diskriminasi, eksploitasi, dan aneka penindasan dari para penguasa zalim. Agama model seperti ini yang sangat disukai para penguasa untuk menjaga kekuasaannya tetap aman, tanpa ada gangguan dari orangorang yang ingin mengamalkan Islam sejati.

Gagasan Syari'ati tentang Islam revoluioner atau Islam pembebasan sejalan dengan gagasan tentang teologi pembebasan (theology of liberation) yang banyak diusung oleh tokohtokoh revolusioner baik di Amerika Latin maupun Asia. Ide dasar pemikiran antara Syari'ati dengan para pengusung teologi pembebasan hampir sama, yakni ingin mendobrak kemapanan lembaga resmi keagamaan (ulama, gereja) yang posisinya selalu berada pada pihak kekuasaan, dan berpaling dari kenyataan ril umatnya yang selalu ditindas oleh kekuasaan itu. Mereka samasama memberontak dan tidak puas dengan seperangkat doktrin yang telah dibuat oleh ulama atau gereja untuk melindungi kepentingan kelas atas dan menindas kelas bawah.Islam revolusioner 
dan teologi pembebasan sama-sama berupaya untuk mengakhiri dominasi lembaga resmi agama dan mengembalikan hak menafsirkan agama itu kepada rakyat, sehingga doktrin-doktrin yang terbentuk adalah ajaran agama sejati yang berpihak pada kepentingan rakyat.

Seperti yang pernah dinyatakan oleh Leonardo Boff, Teologi Pembebasan adalah pantulan pemikiran, sekaligus cerminan dari keadaan nyata, suatu praksis yang sudah ada sebelumnya. Lebih tepatnya, masih menurut Boff, ini adalah pengungkapan atau pengabsahan suatu gerakan sosial yang amat luas, yang muncul pada tahun 1960-an yang melibatkan sektor-sektor penting sistem sosial keagaman, seperti para elit keagamaan, gerakan orang awam, para buruh, serta kelompok-kelompok masyarakat yang berbasis keagamaan (Michael Lowy, 1999: 27).

Teologi Pembebasan adalah produk kerohanian.Dan harus diakui, dengan menyertakan di dalamnya suatu doktri keagamaan yang benar-benar masuk akal, Teologi Pembebasan telah memberikan sumbangsih yang amat besar terhadap perluasan dan penguatan gerakan-gerakan tersebut.Doktrin masuk akal itu telah membentuk suatu pergeseran radikal dari ajaran tradisional keagaman yang mapan. Beberapa diantara doktrin itu adalah ; 1). Gugatan moral dan sosial yang amat keras terhadap ketergantungan kepada kapitalisme sebagai suatu sistem yang tidak adil dan menindas, 2) Penggunaan alat analisis Marxisme dalam rangka memahami sebab-musabab kemiskinan, 3) pilihan khusus pada kaum miskin dan kesetiakawanan terhadap perjuangan mereka menuntut kebebasan, 4) Suatu pembacan baru terhadap teks keagamaan, 5) Perlawanan menentang pemberhalaan sebagai musuh utama agama 6) Kecaman teradap teologi tradisional yang bermuka ganda sebagai hasil dari filsafat Yunani Platonis (Wahono Nitiprawiro, 2000: 2325).

Sejalan dengan kerangka pikir gerakan teologi pembebasan yang diusung oleh kalangan revolusioner di lingkungan agama Katholik, Islam revolusioner atau Islam pembebasan kurang lebih mempunyai kerangka pikir yang sama. Teologi pembebasan berbasis pada kesadaran rohani dan Islam pembebasan juga berbasis pada kesadaran Islam sejati atau otentik.Masing-masing mempunyai tujuan untuk menjadikan agama sebagai sarana untuk memperjuangkan tegaknya keadilan, meruntuhkan segala sistem despotik dan otoriter dan menjaga agar tidak ada penindasan di muka bumi ini.

Sebagaimana yang telah terekam dalam sejarah Islam, bahwa kedatangan Islam adalah untuk merubah status quo serta mengentaskan kelompok yang tertindas dan eksploitasi; mereka inilah yang disebut dengan kelompok masyarakat lemah.Masyarakat yang sebagian anggotanya 
mengeksploitasi sebagian anggota yang lainnya yang lemah dan tertindas, tidak disebut sebagai masyarakat Islam (Islamic society), meskipun mereka menjalankan ritualitas Islam.Ajaran Nabi menyatakan bahwa kemiskinan itu dekat dengan kekufuran, dan menyuruh umatnya untuk berdoa kepada Allah agar dapat terhindar dari keduanya.Penghapusan kemiskinan merupakan syarat begi terciptanya masyarakat Islam. Dalam hadis lain Nabi menyatakan, bahwa sebuah negara dapat bertahan hidup walau di dalamnya ada kekufuran, namun tidak bisa bertahan jika di dalamnya terdapat dhulm (penindasan) (Asghar Ali Engineer, 2003: 7).

Sayangnya, sebagaimana yang telah digelisahkan oleh Syari'ati, Islam yang bersifat revolusioner ini segera menjadi agama yang kental dengan status quo.Islam sarat dengan praktek feodalisme dan para ulama justru menyokong kemapanan yang sudah kuat itu. Mereka lebih banyak menulis buku tentang kaidah-kaidah ritual dan menghabiskan energinya untuk mengupas masalah-masalah furû'iyah dalam syari'at, dan sama sekali mengecilkan arti elan fital Islam dengan menciptakan keadilan sosial dan kepedulian Islam yang aktif terhadap kelompok yang lemah dan tertindas (mustad'afìn). Mereka mengidentifikasi dirinya sebagai mustakbirîn (orang yang kuat dan sombong).

Seperti yang telah disebut di muka, Syari'ati "menuduh" ulama sebagai sumber utama atas penyelewengan ajaran Islam yang bersifat revolusioner.Di tangan ulama, Islam telah menjadi agama "orang mati" yang tidak berdaya melawan "orang-orang yang serakah".Dalam konteks Iran, ulama telah merubah Syi'ah dari kepercayaan revolusioner menjadi ideologi konservatif; menjadi agama negara (din-i dewlati), yang paling tinggi menekankan sikap kedermawanan (philanthropism), paternalisme, pengekangan diri secara sukarela dari kemewahan.Sedangkan pada pihak lain, demikian Syari'ati menggambarkan, ulama mempunyai hubungan organik dengan kemewahan itu sendiri melalui kelas berharta. Karena ulama Syi'ah memperoleh pemasuka dari Khams (sedekah) dari sahm-i Imâm (bagian dari zakat), mereka tak terhindarkan lagi terkait kepada orang kaya, negara tuan tanah, dan pedagang bazaar. Sebagai respon terhadap orang yang mengklaim bahwa ulama Syi'ah lebih independen dibandingkan dengan ulama Sunni.Syari'ati berargumen bahwa hal itu mungkin benar pada masa sebelum Safavi, tetapi tidak demikian setelahnya (Azyumardi Azra, 1996: 79).

Syari'ati lebih jauh menilai, hubungan khusus ulama semacam itu telah menjadikan mereka sebagai instrumen kelas-kelas berharta.Lembaga-lembaga pendidikan Islam dibiayai kaum berharta untuk mencegah ulama berbicara tentang perlunya menyelamatkan kaum 
miskin.Sebaliknya, dengan menggunakan doktrin fikih tentang ekonomi, ulama berusaha mengabsahkan ekploitasi, yang menurutnya bahkan lebih ekploitatif dibandingkan dengan kapitalisme Amerika.Pada akhirnya, Islam telah menjadi khordeh-i burzhuazi (burjuasi kecil).Dan, kaum mullah telah melakukan perkawinan yang tidak suci (unholy marriage) dengan pedagang bazâr.Dalam perkawinan ini, mullah menciptakan agama bagi pedagang, sementara pedagang membuat dunia lebih menyenangkan bagi mullah (Azyumardi Azra, 1996: 80).

Tentu saja kritik yang cukup pedas dari Syari'ati kepada golongan ulama membuat para ulama menberikan reaksi balik.Muthahari, salah sorang ulama terkemuka, memandang Syari'ati telah memperalat Islam untuk tujuan-tujuan politis dan sosialnya.Lebih jauh Muthahari menilai, aktivisme politik protes Syari'ati menimbulkan tekanan politis yang sulit untuk dipikul oleh sebuah lembaga keagamaan seperti Hussainiyeh Ersyad dari rezim Syah (Abdulaziz Sachedina, 1983: 207. Bandingkan dengan Shahrough Akhavi dalam Nikki R. Keddie (ed.), 1983: 45). Dan Memang, setelah Syari'ati banyak mengkritik lembaga ulama dan rezim, Hussainiyeh Ersyad akhirnya ditutup paksa oleh pasukan keamanan. Selain Muthahhari, masih banyak ulama sumber panutan (marja' taqlid) seperti Ayâtullah Khû'i, Milani, Rûhani, dan Thabathâba'i yang juga turut mengecam suara-suara kritis Syari'ati.Bahkan mereka mengeluarkan fatwa yang melarang membeli, menjual, dan membaca tulisan-tulisan Syari'ati (Ali Rahnema (ed.), 1996: 234).

Setelah Syari'ati mengkritik ulama yang dinilainya sebagai akhund (sebuah istilah pejoratif untuk menyebut ulama yang berpengetahuan dangkal)., Syari'ati lantas menyampaikan tipikal ulama ideal. Menurutnya, ulama ideal, secara sederhana, adalah ulama aktivis, yang menggalang massa untuk melakukan gerakan protes. Sehingga dalam hal ini, ia menjadikan ayahnya sendiri dan Ayâtullah Muhammad Baqir Sadr (dihukum mati oleh pemerintah Republik Islam Iran tahun 1979) atau pemikir aktivis dari kalangan Sunni seperti al-Afghani sebagai idolanya (Azyumardi Azra, 1996: 82). Khomaeni tentu saja cocok dengan kerangka Syari'ati mengenai ulama.Tetapi Syari'ati tidak pernah menyatakan perasaannya secara terbuka tentang Khomaeni.Informasi yang ada nampaknya memberikan indikasi bahwa Syari'ati mengakui Khomaeni sebagai pemimpin besar.

Walaupun Ali Syari'ati tampak sebangun dengan Imam Khomeini dalam melihat realitas politik Iran dan bagaimana faham Syi'ah berhadap-hadapan dengan faham resmi yang dibanguh rezim, akan tetapi ada satu hal yang membedakan antara keduanya, yaitu pada persoalan siapa yang akan menjadi lokomotif pembaharu atau revolusi. Khomeini cenderung mengedepankan 
peran ulama formal (para mullah) sedangkan Syari'ati pada kekuatan kelompok rausanfikr.Kelompok rausanfikr adalah sekelompok orang yang melakukan pembaharuan di kalangan umat dengan menjadikan faham Islam sebagai basis epistemologi dan aksiologisnya.Islam yang demikian itu, kata Syari'ati, adalah "Islam protestan” yang bisa menjadi kekuatan sosio-kultural untuk menghilangkan abad kegelapan dunia Islam dan menciptakan suatu abad renaisance (Mungol Buyat dalam John L. Esposito (ed.), 1980: 161).

Pemikiran-pemikiran Ali Syari'ati tentang Islam secara konsisten berada dalam aras Islam progresif dan revolusioner. Corak Islam yang demikian itu berangkat dari faham bahwa dalam ajaran Islam, Tuhan telah menugaskan kepada manusia sebagai khalîfah-Nya di muka bumi.Khalîfah dalam hal ini adalah pemangku tugas pembaharu dan selalu memimpin dunia dengan keadilan dan kearifannya. Jika ditemukan dalam penggalan sejarah manusia-manusia serakah yang aksinya menindas dan memperkosa hak-hak manusia lain, maka menjadi tugas khalîfah untuk menyingkirkan jenis manusia itu dari muka bumi. Khalîfah haruslah dalam posisi pro-aktif memperjuangkan prinsip-prinsip keadilan, bukan manusia pasrah yang selalu menerima nasib secara taken for granted. Demikianlah yang dapat dikategorikan sebagai ajaran Islam progresif sebagaimana yang digagas oleh Ali Syari'ati.

Kata kunci progresifitas Islam adalah peran aktif dalam sejarah kemanusiaan.Islam bukan agama pasrah yang hanya berfikir tentang kehidupan akherat dan tidak melibatkan diri dalam dinamika sejarah sosial-politik manusia. Bentuk ajaran agama yang demikian ini yang telah melahirkan banyak kritik dari Karl Marx, sang revolusioner yang telah dituduh anti agama. Agama pasrah ini adalah agama candu yang akan melanggengkan segala bentuk kesewenangwenangan dan penindasan. Dalam posisi ini, kata Marx, mereka yang tertindas akan dihibur oleh ajaran yang mengatakan bahwa penderitaan itu adalah taqdir Tuhan dan pahala mereka adalah surga (Ian Adams, 2004: 243). Dan Syari'ati sangat setuju dengan pandangan Marx itu, khususnya dalam aspek bagaimana bentuk-bentuk penindasan itu tidak dilanggengkan oleh ajaran agama. Jika ini yang terjadi, maka Syari'ati pun akan senada dengan Marx, bahwa agama adalah candu (opium).

Bagi Syari'ati, Islam harus diekspresikan dalam tindakan. Hal ini dimulai dari menghidupkan kembali realitas abadi yang dipelajari kaum Syi'ah untuk memahami hakekat kehidupan. Teladan Imam Husein di padang Karbala harus menjadi inspirasi bagi semua umat yang tertindas dan terasingkan di dunia ini. Jika kaum Syi'ah mengikuti teladan Imam Husein dan 
memimpin semua bangsa di Dunia Ketiga dalam kampanye melawan tirani, mereka dapat mendorong Imam yang selama ini gha'ib dapat hadir kembali (Karen Armstrong, 2000: 401-402).

Syi'ah, kata Syari'ati, harus dihidupkan kembali. Seperti telah dikemukakan di muka, Syi'ah Ali dan Husein yang asli telah dihapus oleh apa yang Syari'ati sebut "Syi' ah Safavi”. Suatu keimanan yang aktif dan dinamis telah dirubah menjadi masalah pribadi yang pasif, padahal menghilangnya Imam Gha'ib berarti bahwa misi Nabi dan para Imam sebenarnya dilanjutkan oleh umat. Karena itu, masa kegha'iban adalah masa demokrasi. Orang awam tidak boleh lagi menghamba kepada para mujtahîd dan dipaksa meniru (taqlîd) perilaku keagamaan mereka, seperti yang dikehendaki oleh Syi'ah Safavi.Setiap Muslim harus tunduk kepada Tuhan semata, demikian penegasan Syari'ati, dan mempertanggungjawabkan kehidupannya sendiri. Selain ini adalah musyrik dan menyimpang dari Islam, mengubah ketaatan kepada Tuhan menjadi ketaatan tanpa jiwa kepada peraturan-peraturan.Rakyat harus memilih pemimpin mereka sendiri; mereka harus dimintai pendapatnya, sesuai dengan ajaran syûra.Kekuasaan ulama harus diakhiri, dan sebagai gantinya, kata Syari'ati, "kaum intelektual tercerahkan" (rausanfikr) menjadi pemimpin umat yang baru (Ali Syari'ati, 1986: 132). Untuk pernyataan yang terakhir inilah, Syari'ati berbeda pandangan secara mendasar dengan Imam Khomeini dimana Khomeini lebih menekankan kepemimpinan ideal ada di tangan ulama.

Syari'ati berpendapat bahwa Islam lebih dinamis dari pada agama lainnya.Terminologi Islam memperlihatkan tujuan yang progresif. Di Barat, kata "politik" berasal dari bahasa Yunani "polis" (kota), sebagai suatu unit administrasi yang statis, tetapi padanan kata Islamnya adalah "siyasah", yang secara harfiyah berarti "menjinakkan seokor kuda liar,", suatu proses yang amengandung makna perjuangan yang kuat untuk memunculkan kesempurnaan yang inheren (Michael J. Fischer, 1990: 154-155).

\section{Tauhîd Sebagai Dasar Islam Pembebasan}

Pandangan Islam Ali Syari'ati yang progresif dan revolusioner bersumber pada satu sistem keyakinan yaitu tauhîd.Di tangan Syari'ati, istilah teknis tradisional tersebut menjelma menjadi radikal dan terkesan Jacobin, sosialis, idealis, sekaligus transhistoris.Dia menegakkan tauhîd sebagai pedang untuk memerangi perpecahan agama, pengotak-otakan pengetahuan, pemisahan Tuhan dengan manusia, serta ketidakbermaknaan kejadian sejarah yang terputus-putus (Ali Syari' ati, 1986: 150). 
Tauhîd dalam hal ini adalah pandangan dunia (world view) mistis-filosofis yang melihat jagad raya sebagai organisme hidup tanpa dikotomisasi, semua adalah kesatuan (unity) dalam trinitas antara tiga hipotesis: Tuhan, manusia, dan alam. Bagi Syari'ati, tauhîd menyatakan bahwa alam adalah sebuah totalitas kreasi harmoni. Tanggungjawab seorang Muslim adalah untuk mengenali dan menerima tututan realitas dan menggerakkannya secara massif:

My world-view consist of tauhîd. Tauhîd in the sense of oneness of God is of course accepted by all monotheist. But tauhîd as a world-view in the sense I intend in my theory means regarding the whole universe as a unity. (Pandangan dunia sayaberasal daritauhîd.Tauhîd dalam pengertian keesaan Tuhan yang menjadi wacana yang diterima oleh semua penganut paham Ke-Tuhan-an Yang MahaEsa (monoteisme).Tetapi Tauhîdsebagai suatu pandangan dunia dalam pengertian teori yang saya tawarkan adalah mengenai keseluruhan alam semesta serbagai suatu kesatuan (Ali Syari'ati, 1979: 82).

Bagi Syari'ati, kesatuan semesta raya adalah soal naluri dan keimanan. Hal ini tidak mungkin didapatkan melalui pembuktian empiris, sebab pengamatan terhadap dunia fenomena justru menggiringnya pada kesimpulan tentang keunikan dan keragaman.Dunia penuh dengan perbedaan dan kontradiksi, dan empirisme mencoba untuk mewadahinya tetapi tidak untuk mengatasinya.Logika bisa jadi membantu, namun tidak pernah mencukupi, karena logika tidak pernah sanggup menunjukkan kemencukupannya sendiri. Lebih dari itu, apa yang dimaksud kesatuan oleh Syari'ati meliputi juga kesatuan perasaan dan pengetahuan, cinta dan kebenaran, dan tentu saja secara definitif tidak dapat ditunjukkan di dalam wilayah pengetahuan belaka (Ali Syari'ati, "Fatimeh is $\quad$ Fatimeh", dalam http://www.iranchamber.com/personalities/ashariati/works/fatima_is_fatima5.php, diakses tanggal 25 Januari 2006).

Syari'ati mengangkat logika, walaupun kemudian ia mengakui betapa tak memadainya logika sebagai perangkat pembuktian. Dengan memodifikasi dan menggambarkan kembali ungkapan para eksistensialis, ia mengatakan bahwa manusia, sebagai bagian dari semesta raya, hanya akan mempunyai makna jika keberadaan semesta raya sendiri bermakna. Juga tidak mungkin bagi manusia untuk memiliki pilihan dan tanggung jawab di dalam dunia tanpa adanya kesadaran, kehendak, arah, dan akal.Manusia senantiasa berpartisipasi dalam Wujud; jika Wujud itu bersifat absurt, absurt pulalah segala sesuatu (Robert D. Lee, 2000: 151). Paham Syari'ati tentang kehendak bebas manusia (free will), sekilas tampak seperti paham Mu'tazilah yang lebih 
menekankan aspek keadilan Tuhan ketimbang kekuasaan Tuhan. Konsekwensi dari paham ini adalah bahwa manusia diberi keleluasaan untuk bertindak yang berakibat pada terkenainya manusia akan tanggung jawab. Kerusakan dan kebaikan yang tampak di muka bumi ini adalah akibat dari tangan manusia, sehingga jika terdapat kesewenang-wenangan atau penindasan atau perilaku destruktif lainnya dari kelompok manusia, maka adalah tanggung jawab dari kelompok manusia lain untuk menghentikan perilaku itu. Karena jika tidak, maka semua manusia akan merasakan secara bersama-sama akibat penindasan dan kesewenang-wenangan itu. Taqdir dalam hal ini lebih dipahami sebagai hukum Tuhan yang berlaku di alam ini yang bersifat tetap, dari pada sebuah ketetapan Tuhan atas segala sesuatu sebagai pancaran dari ke-Maha Kuasa-Nya (Ali Syari' ati dalam Charles Kurzman (ed.), 2003: 302-305).

Adalah wajar jika paham kebebasan manusia Syari'ati dekat dengan paham Mu'tazilah ketimbang Asy'ariyah, karena secara normatif ajaran Syi'ah tentang hal ini memang pada dasarnya cederung kepada paham Mu'tazilah yang lebih menekankan pada keadilan Tuhan, dan sekaligus pada titik inilah perbedaan Syi'ah dengan Sunni.Allamah M.H. Thabathaba'i telah mengupas masalah ini dalam bukunya, Shi'ite Islam. Ia menyatakan bahwa paham Asy'âriyah (Sunni) lebih menekankan pada irâdah atau kehendak Tuhan yang berarti pula berkeyakinan bahwa apa pun yang dikehendaki Tuhan adalah adil, sebab itu dikehendaki Tuhan, dan akal, dalam pengertian tertentu, ditundukkan pada kehendak ini dan "dengan sukarela menyakini keunggulan kehendak Tuhan (voluntarism). Berbeda dengan Sunni, Syi'ah beranggapan bahwa sifat keadilan dianggap sebagai bawaaan sifat Ilâhi. Tuhan tidak berbuat dalam cara yang tidak adil sebab adalah sifat-Nya untuk berlaku adil. Bagi-Nya, berlaku tidak adil adalah sama artinya dengan memperkosa sifat-Nya sendiri, yang dalam hal ini adalah mustahil. Lebih lanjut Thabathaba'i menyatakan, bahwa akal dapat menilai suatu tindakan, sebagai adil atau tidak adil, dan penilaian ini tidak sepenuhnya batal oleh keyakinan akan keunggulan kehendak Tuhan (Allamah M.H. Thabathaba'i, 1979: 10. Bandingkan dengan Harun Nasution, t.t: 102-128).

Syahrough Akhavi melihat sepasang kontradiksi yang saling berhubungan dalam pemikiran Syari'ati.Pertama, dia heran bagaimana Syari'ati dapat menegaskan otonomi manusiayang bebas untuk memilih sesuatu, bahkan yang tidak disenangi Tuhan-sebagai pembentuk utama sejarah manusia sekaligus menegaskan Tuhan sebagai "Wujud yang Absolut dan Tersembunyi" sebagai pelindung multak alam semesta raya. Kedua, dia mengamati bahwa Syari'ati, yang ternyata seorang fenomenolog, yakin bahwa manusia dengan dirinya tidak 
mungkin mencapai hakekat kebenaran.Mereka harus memandang obyek-obyek material dan ideide itu (membaca al-Qur'an, misalnya) sebagai tanda-tanda kebenaran, namun tidak boleh memandangnya sebagai kebenaran itu sendiri.Apakah manusia dapat dipandang otonom sepenuhnya jika pilihan otonom itu merupakan cerminan dari "penampakan realitas"? (Shahrough Akhavi, dalam Nikki R. Keddie (ed.), 1983: 131-135).

Jika tauhîd dalam pandangan Syari'ati adalah kesatuan antara Tuhan, manusia dan alam semesta, maka kondisi masyarakat yang penuh diskriminasi sosial, ketidakadilan, dan kesewenang-wenangan dapat dikategorikan sebagai Syirk, lawan dari tauhîd (John Obert Voll, 1982: 301. Lihat juga Hassan Hanafi, t.t: 3-4). Dalam masyarakat Islam yang ber-tauhîd, terdapat kesatuan yang utuh yang bukan merupakan konstruk hukum :

All human being not same solely: they arebrother. Difference between equation and brotherhood is clear. Equation is concept punish, whereas brotherhood express the keseragaman of essence and character of all human being; all human being come from one single source, any their husk colour. Both men and woman are same... men And woman created from same substansi materials and, at the time of same, by same creator. (Semua manusia tidak semata-mata sama: mereka adalah saudara. Perbedaan antara persamaan dan persaudaraan adalah jelas.Persamaan adalah konsep hukum, sementara persaudaraan menyatakan keseragaman hakekat dan watak semua manusia; semua manusia berasal dari satu sumber tunggal, apapun warna kulit mereka. Kedua laki-laki dan perempuan adalah sama... Laki-laki dan perempuan diciptakan dari substansi dan bahan yang sama, pada saat yang sama, oleh pencipta yang sama) (Ali Syari'ati, 1986: 77).

Tauhîd memandang dunia sebagai suatu imperium, sedangkan lawannya Syirk memandang dunia sebagai sistem feodal.Dengan pandangan ini maka dunia memiliki kehendak, kesadaran diri, tanggap, cita-cita, dan tujuan.Dengan bersandar pada keyakinan ini, Syari'ati menolak politheisme, dualisme, dan trinitarianisme.Ia hanya percaya pada tauhîd, monotheisme. Monotheisme menolak segala pengakuan dan keyakinan mausia atas tuhan-tuhan palsu.Jika pada zaman Jâhiliyyah, tuhan-tuhan palsu itu dimanifestasikan dalam wujud berhala-berhala, maka pada zaman modern ini, menurut Syari'ati, tuhan-tuhan palsu terwujud dalam banyak aspek dan bidang yang lebih luas dan komplek dari sekadar berhala-berhala sesembahan. Tuhan-tuhan itu lebih berbentuk sistem tirani yang sarat dengan penindasan, atau kemegahan dunia yang ketika meraihnya harus merampas hak-hak orang lain (Ali Syari'ati, "Hajj", dalam http://www.shariati.com//haji, diakses tanggal 25 Januari 2006). 
Syari'ati dalam bukunya Eslamshenasi (Islamology) menyatakan bahwa kesyirikan tidak saja berarti menolak Tuhan.Perwujudan modern kesyirikan dapat dijumpai pada kasus di mana orang melakukan tindakan yang merupakan monopoli Tuhan, dengan begitu berarti menempatkan dirinya sebagai pengganti Tuhan. Memuja pribadi, atau hubungan kemanusiaan apa pun di mana orang bergantung pada, secara membuta mengikuti, tunduk patuh pada orang lain, merupakan contoh kesyirikan. Syari'ati menulis: "Orang yang ... memaksaan kehendaknya kepada orang lain, dan memerintah menurut kemauannya sendiri, berarti dia telah mengakui sebagai Tuhan, dan barangsiapa menerima pengakuan seperti itu, berarti dia syirk, karena perintah, kehendak, kekuasan, dominasi, dan pemilihan mutlak itu merupakan monopoli Tuhan saja" (Ali Rahmena (ed), 1996: 228)

Masih dalam buku Eslamshenasi, Syari'ati memperlihatkan kenapa Muslim sejati harus menentang kesyirikan yang disebutnya sebagai pemerintahan dan otoritas orang-orang yang hendak menempatkan dirinya sebagai penganti Tuhan.Dengan menyebutkan bahwa manusia adalah katalisator perubahan, Syari'ati bermaksud melepaskan manusia dari ketakutan menentang otoritas yang zalim.Di luarnya, Syari'ati membuat generalisasi yang agak naif, dengan mengkhususkan trinitas jahat, seperti bodoh, takut dan serakan, sebagai sumber segala bentuk penyimpangan, dosa, kejahatan, kekejian, kehinaan, keburukan dan bahkan keterbelakangan.Ahli tauhîd, orang yang meng-Esa-kan Tuhan, menurut Syari'ati, kebal terhadap trinitas jahat ini. Perilakunya bukan diatur oleh kegunaan, namun oleh kesadaran akan fakta bahwa hanya Tuhanlah yang harus ditakuti dan dihormati tanpa syarat. Sedangkan segenap makhluq-Nya tak ada dayanya di hadapan-Nya. Syari'ati mengatakan bahwa ahli tauhîd memiliki ciri-ciri yang akan melahirkan revolusioner Islam ideal. Ahli tauhîd itu "mandiri", tidak pernah takut, peduli pada orang lain, terpercaya, dan hanya tunduk kepada Tuhan. (Ali Rahmena (ed), 1996: 228-229)

Generalisasi naif Syari'ati menjadi ajakan politik yang bersifat menggembleng, untuk menolak, menentang dan melawan segenap sumber kekuatan syirik, seperti kediktatoran, sistem kapitalis dann ulama resmi.Syari'ati juga bermaksud menyebut Muslim sebagai satu-satunya agen sosial yang dapat melahirkan kesempatan historis dan revolusioner seperti ini, karena sebagai ahli tauhîd, mereka tidak mungkin hidup damai dengan kesyirikan.Pandangan dunia syirik didasarkan pada, dan berkembang berkat, kontradiksi.Tauhîd sebagai pandangan dunia, tujuannya adalah menghapus kontradiksi.Ini merupakan ajakan untuk "bangkit melawan" segala tuhan palsu (Ali Rahmena (ed), 1996: 299). 
Menurut Syari'ati, sebagai makhluq yang berdimensi ganda (ruh dan jasad), manusia tidak dapat memisahkan dirinya dari agama dan politik seperti yang telah diupayakan oleh rezim Syah. Manusia mempunyai kehidupan fisik dan spiritual, membutuhkan mitos dan logos, dan setiap masyarakat harus mempunyai dimensi transedental. Bagi Syari'ati, memisahkan agama dengan politik sama halnya mengingkari pandangan hidup tauhîd (Eko Supriyadi, 2003: 166). Dalam persoalan relasi antara agama dengan politik, Syari'ati nampaknya cenderung menempatkan kedua entitas itu pada posisi yang tidak terpisah.Berlawanan dengan pandangan dunia sekuler yang secara tegas memisahkan urusan politik dengan agama.

Dalam pandangan hidup tauhîd, tidak ada kontradiksi antara manusia dengan alam, ruh dengan badan, dunia dengan akherat, dan antara spirit dengan materi.Dengan demikian tauhîd menolak segala bentuk kontradiksi legal, sosial, politik, rasial, nasional, teritorial, maupun genetik.Sebaliknya segala pertentangan yang muncul di dunia adalah disebabkan oleh pandangan hidup syirk, yang ditandai dengan diskriminasi rasial dan kelas.Konsekwensi pandangan hidup tauhîd adalah menolak ketergantungan manusia terhadap kekuatan sosial tertentu, tetapi mengaitkan manusia dengan kesadaran pada kehendak Tuhan.Segala gerak kosmos harus memusat pada tauhîd, sebagaimana digambarkan oleh gerak memusat dalam tawaf Ka'bah.

This is an equation of the whole world. It is an example of a system based on the idea of monotheism which encompasses the orientation of a particle (man). Allah is the center of existence; He is the focus of this ephemeral world. In contrast, you are a moving particle changing your position from what you are to what you ought to be. Yet in all positions and during all times, maintain a constant distance with "Kaaba" or with Allah! The distance depends upon the path that you have chosen in this system.(Inilah sebuah persamaan dari seluruh dunia.Inilah contoh dari sebuah sistem yang berdasarkan ide monotheisme (tauhîd) yang mencakup orientasi sebuah partikel (manusia).Allah adalah pusat eksistensi; Dia adalah titik fokus dari dunia yang fana ini.Sebaliknya engkau adalah sebuah partikel yang bergerak dengan mengubah posisimu sebagai manusia seperti yang sekarang kepada posisimu seperti yang seharusnya.Tetapi di setiap posisi itu dan di setiap saat di antara engkau dengan Ka'bah atau Allah senantiasa ada jarak, dan jarak ini tergantung kepada jalan yang telah engkau pilih di dalam sistem ini) (Ali Syari'ati, "Hajj”, dalam http://www.shariati.com//haji, diakses tanggal 25 Januari 2006).

Pandangan dunia tauhîd, lanjut Syari'ati, menuntut manusia hanya takut kepada satu kekuatan, yaitu kekuatan Tuhan, dan selain itu adalah kekuatan yang tidak mutlak atau palsu.Tauhîd menjamin kebebasan manusia dan memuliakan untuk semata kepadaNya.Pandangan ini menggerakkan manusia untuk melawan segala kekuatan, dominasi belenggu, dan kenistaan oleh manusia atas manusia.Tauhîd memiliki esensi sebagai gagasan yang bekerja untuk keadilan, solidaritas, dan pembebasan. Kebebasan manusia dimulai ketika Tuhan 
meniupkan ruh dan memberinya kepercayaan.Manusia mempunyai hubungan dengan Tuhan yang memnadang kesatuan Tuhan dengan dirinya yang mengarah kepada kesempurnaan.Itulah sebenarnya gerakan manusia ke arah kesempurnaan (takâmul) dan peninggian (ta'âli). Menurut Syari'ati, tiga simbol manusia pada tahap kesempurnaan tercermin pada: (1) kesadaran diri, (2) kemauan bebas, dan (3) daya cipta. Dari tiga filosofis dasar itu, mengutip pernyataan Descartes: "cogito ergo sum" dan Gidden: "saya merasa maka saya ada", maka Syari'ati mereformulasi itu menjadi: "saya memberontak maka saya ada". Formula ini menggambarkan manusia dalam tahap sempurna. Tiga simbol itu bisa membawa manusia dalam tahap sempurna jika ia berupaya menanamkan tiga simbol pada sifat-sifat Ilahiyah, serta menjalankan fungsinya sebagai wakil pengawas Tuhan di muka bumi (Muhammad Nafis, dalam M. Deden Ridwan (ed.), 1999: 109).

Setelah tauhîd dibakukan menjadi suatu padangan dunia, maka Syari'ati, memantabkan gagasan revolusionernya dengan menunjukkan perlunya totalitas keterlibatan, percurahan, dan segala potensi diri untuk mengakumulasi kekuatan masyarakat.Untuk tujuan itulah, Syari'ati merujuk kepada salah satu doktrin Islam yang sangat pupuler dan mendasar - terlebih lagi dalam tradisi Syi'ah di Iran -, yaitu doktrin kesyahidan (syahâdah). Doktrin syâhid mengacu kepada kematian Husein di padang Karbala oleh pasukan Yazid, rezim penguasa saat itu. Dengan doktrin ini, maka Syari'ati mengajak seluruh masyarakat Iran untuk merelakan dirinya menuju totalitas pengorbanan tertinggi, yaitu mati di jalan Tuhan. Bagi Syari'ati, syâhid adalah jantung sejarah yang senantiasa menuntut orang beriman untuk siap berkorban baik dengan jiwa dan raga, rela mati demi satu tujuan kemenangan.

A Shahid is the one who negates his whole existence for the sacred ideal in which we all believe. It is natural then that all the sacredness of that ideal and goal transports itself to his existence. True, that his existence has suddenly become nonexistent, but he has absorbed the whole value of the idea for which he has negated himself. No wonder then, that he, in the mind of the people, becomes sacredness itself. In this way, man becomes absolute man, because he is no longer a person, an individual. He is "thought." He had been an individual who sacrificed himself for "thought" Now he is "thought" itself. For this reason, we do not recognize Hussein as a particular person who is the son of Ali. Hussein is a name for Islam, justice, imamat, and divine unity. We do not praise him as an individual in order to evaluate him and rank him among shuhada. This issue is not relevant. When we speak of Hussein, we do not mean Hussein as a person. Hussein was that individual who negated himself with abso- lute sincerity, with the utmost magnificence within human power, for an absolute and sacred value. From him remains nothing but a name. His content is no longer an individual, but is a thought. He has trans-formed himself into the very school [for which he has negated him-self. 
(syâhidadalah siapa yang meniadakan eksistensinya yang utuh untuk sesuatu yang ideal dan suci di mana kita semua percaya. Adalah alami kemudian bahwa semua pengorbanan yang ideal dan tujuan mengantarkan dirinya sendiri kepada eksistensi. Benar, bahwa eksistensinyanya secara tiba-tiba menjaditidak ada, tetapi ia telah menyerap keseluruhan nilai gagasan di mana ia telah meniadakan dirinya sendiri. Tidak heran kemudian, bahwa ia, di dalam pikiran orang-orang, menjadikandirinya suci. Dengan cara ini, manusia menjadi manusia yang mutlak, sebab ia tidak lagi seorang pribadi, seorang individu. Ia adalah "pikiran." Iamenjadi individu yang mengorbankandirinya sendiri untuk "pikiran" Sekarang ia adalah "dipikirkan" dirinya sendiri. Karena alasan ini, kita tidak mengenali Hussein sebagai orang putra Ali. Hussein adalah suatu nama untuk Islam, keadilan, imâmah, dan kesatuan ilahi. Kita tidak memuji dia sebagai suatu individu dalam rangka mengevaluasi dia dan menggolongkan dia diantarasyuhadâ.Isu ini tidaklah relevan.Ketika kita berbicara tentang Hussein, kita tidak memaknai Hussein sebagai individu.Hussein adalah bahwa individu yang meniadakan dirinya sendiri dengan ketulusan absolout, dengan kecemerlangan yang luar biasa dalam kuasamanusia, untuk suatu kemutlakan dan nilai suci. Dari dia, yang tertinggal tak lain hanya suatu nama. Isinya tidak lagi perorangan, tetapi adalah suatu pemikiran.Iamentransformasikan dirinya ke dalam keseluruhanpemikiran [di mana ia telah meniadakan dirinya) (Ali Syari'ati, "Jihad and Shahadat", dalam http://www.iranchamber.com/personalities/ashariati/works/jihad_shahadat.php, diakses pada 22 Pebruari 2006)

\section{Penutup}

Dalam pemikiran Syari'ati, Islam bukanlah agama yang hanya memperhatikan aspek spiritual dan moral atau hanya sekadar hubungan antara hamba dengan Sang Khaliq (Hablun min Allah), tetapi lebih dari itu, Islam adalah sebuah ideologi emansipasi dan pembebasan. Islam yang demikian adalah Islam Syi'ah awal, yakni Islam Syi'ah revolusioner yang dipersonifikasikan Abu Zar alGhifari dengan kepapaannya, dan Imam Husein dengan kesyahidannya. Keduanya merupakan simbol perjuangan abadi ketertindasan melawan penguasa yang zalim.Pandangan Islam Ali Syari'ati yang progresif dan revolusioner bersumber pada satu sistem keyakinan yaitu tauhîd.Tauhîd dalam pandangan Syari'ati adalah kesatuan antara Tuhan, manusia dan alam semesta, maka kondisi masyarakat yang penuh diskriminasi sosial, ketidakadilan, dan kesewenang-wenangan dapat dikategorikan sebagai Syirk, lawan dari tauhîd. 


\section{Daftar Pustaka}

Abdulaziz Sachedina, 1983. "Ali Syari' ati: Ideologue of the Iranian Revolution”, dalam John L. Esposito (ed.), Voices of Resurgent Islam (New York, Oxford: Oxford University Press.

Ali Rahnema, 1996. “Ali Syari’ati: Guru, Penceramah, Pemberontak”, dalam Ali Rahnema (ed.), Para Perintis Zaman Baru Islam, Bandung: Mizan.

Ali Syari'ati. 2006. "And Once Again Abu-Dhar", dalam http://www.iranchamber.com/personalities/ashariati/works/once_again_abu_dhar7.php , diakses tanggal 22 Februari.

Ali Syari’ati, 2006. “Hajj”, dalam http://www.shariati.com//hajj, diakses tanggal 25 Januari.

Ali Syari'ati, 2003. "Islam dan Kemanusiaan”, dalam Charles Kurzman (ed.), Wacana Islam Liberal: Pemikiran Islam Kontemporer Tentang Isu-Isu Global, terj. Bahrul Ulum, Jakarta: Paramadina.

Ali

Syari'ati, 2006. "Jihad and Shahadat", dalam http://www.iranchamber.com/personalities/ashariati/works/jihad_shahadat.php, diakses pada 22 Februari.

Ali Syari'ati, 2006. "Red Shi'ism (the religion of martyrdom) vs. Black Shi'ism (the religion of mourning)", dalam http://www.iranchamber.com/personalities/ashariati/works/red_black_shiism.php, diakses tanggal 20 Februari.

Ali Syari' ati, 1979. On the Sosiology of Islam, Berkeley: Mizan Press.

Ali Syari'ati, 1986. What Is To Be Done: The Enlightened and Thinkers and Islamic Renaisance, terj. Farhang Rajaee, Houston: IRIS.

Ali Syari'ati, 2006. "Fatimeh is Fatimeh", dalam http://www.iranchamber.com/personalities/ashariati/works/fatima_is_fatima5.php, diakses tanggal 25 Januari.

Allamah M.H. Thabathaba'i, 1979. Islam Syi'ah: Asal-Usul dan Perkembangannya, terj. Djohan Effendi, Jakarta: PT. Temprint.

Asghar Ali Engineer, 2003. Islam dan Teologi Pembebasan, terj. Agung Prihantoro, Yogyakarta: Pustaka Pelajar.

Azyumardi Azra, 1996. “Akar-Akar Ideologis Revolusi Iran: Filsafat Pergerakan Ali Syari'ati”, dalam Azyumardi Azra, Pergolakan Islam Politik; Dari Fundamentalisme, Modernisme Hingga Post-Modernisme, Jakarta: Paramadina. 
Eko Supriyadi, 2003. Sosialisme Islam: Pemikiran Ali Syari'ati, Yogyakarta: Pustaka Pelajar

Harun Nasution, t.t. Teologi Islam: Aliran-Aliran Sejarah Analisa Perbandingan, Jakarta: Yayasan Penerbit Universitas Indonesia.

Hassan Hanafi, t.t. Min Aqîdah ilâ al-Saurah: al-Muqaddimât al-Nazariyât, Beirut: Dâr al-Tanwîr lî al-Tibâ'ah wa al-Nasr.

Ian Adams, 2004. Ideologi Politik Mutakhir: Konsep, Ragam, Kritik, dan Masa Depannya, terj. Ali Noerzaman, Yogyakarta: CV. Qalam.

John Obert Voll, 198. Islam Continuity and Change in the Modern World, USA: Westview press

Karen Armstrong, 2000. The Battle For God, New York: Alfred A. Knopf.

Michael J. Fischer, 1990. Iran: From Religious Dispute to Revolution, Cambridge, Mass, London: Cambridge University Press.

Michael Lowy, 1999. Teologi Pembebasan, Yogyakarta: Pustaka Pelajar.

Muhammad Nafis, 1999. "Dari Cengkeraman Penjara Ego Memburu Revolusi: Memahami "Kemelut" Tokoh Pemberontak", dalam M. Deden Ridwan (ed.), Melawan Hegemoni Barat: Ali Syari'ati dalam Sorotan Cendekiawan Indonesia, Jakarta: Penerbit Lentera.

Mungol Buyat, 1980. "Islam in Pahlevi and Post-Pahlevi Iran; A Cultural Revolution?", dalam John L. Esposito (ed.), Islam and Development, New York: Syracuse University Press.

Robert D. Lee, 2000. "Ali Shari'ati”, dalam Mencari Islam Autentik: Dari Nalar Puitis Iqbal, Hingga Nalar Kritis Arkoun, terj. Ahmad Baiquni, Bandung: Mizan.

Shahrough Akhavi, 1983. "Shari'ati's Social Thought”, dalam Nikki R. Keddie (ed.), Religion and Politics in Iran, New Haven: Yale University Press.

Syari' ati, 1982. Histoire et Destinée, terj. F. Hamed dan M. Yavari-d' Hellencourt, Paris: Sindbad

Wahono Nitiprawiro, 2000. Teologi Pembebasan: Sejarah, Metode, Praksis, dan Isinya, Yogyakarta: LkiS 